\title{
KETAHANAN PANGAN RUMAH TANGGA DI DESA PANGHASIL DAMAR KABUPATEN LAMPUNG BARAT
}

\author{
(Household Food Security in Village Producing Resin In Lampung Barat District)
}

Jimmy Manesa ${ }^{1}$, Yayuk F. Baliwati ${ }^{2}$, dan Ikeu Tanziha ${ }^{2}$

${ }^{1}$ Program Studi Manajemen Ketahahan Pangan (MKP), Sekolah Pascasarjana, IPB.
2 Departemen Gizi Masyarakat, Fakultas Ekologi Manusia (FEMA), IPB
Tel: 0251-8628304/8621258; Fax: 0251-8625846/8622276

\begin{abstract}
Repong is a forest management system which inherently conducted by community in Lampung Barat Coast. The objective of this research were to analyze: 1) household socio economic characteristics, 2) household food access, 3) household food security, 4) socio economic factors that influence household food security. This research was conducted by using retrospective design. The location was in Penengahan Village, Karya Penggawa Subdistrict, Lampung Barat District that chosen purposively with consideration that the village is the main village producing resin. The samples were 30 households who own repong and 30 households who do not own repong that chosen snowbally. The result of the research shows that: 1) almost all (93.3\% household who own repong work as farmer, while half of household who do not own repong work as farmer $(46.67 \%)$, service $(40 \%)$, and trading $(13.33 \%) ; 2$ ) there is $30 \%$ of household who own repong and $36.7 \%$ of household who do not own repong that have low food access; 3) only $33.33 \%$ of household who own repong and $23.33 \%$ household who do not own repong are food secure; 4) factors that significantly influence energy consumption level are number of household member, size of repong, and food expenditure; factors that significantly influence protein consumption are number of household member and food expenditure; factors that significantly influence consumption diversity are number of household member and size of repong.
\end{abstract}

Keywords: repong, food access, food security

\section{PENDAHULUAN}

Kabupaten Lampung Barat memiliki luas wilayah 495040 ha. Sekitar 380092.37 ha atau 76.78\% luasan tersebut merupakan kawasan hutan. Dengan demikian hanya 114948 ha atau 23.22\% luas wilayah Kabupaten Lampung Barat yang dapat digunakan untuk pemukiman dan kegiatan budidaya. Terbatasnya lahan budidaya berakibat pada luasnya perambahan kawasan hutan, terutama untuk perkebunan kopi monokultur. Saat ini 247060 ha atau 65\% kawasan hutan Lampung Barat telah berubah menjadi lahan kritis.

Penggalian kembali kearifan lokal atau etika tradisional bisa menjadi alternatif di tengah dominasi ilmu pengetahuan dan teknologi modern yang cenderung mengabaikan etika dan lingkungan hidup (Keraf, 2006). Di bagian pesisir Lampung Barat penduduk lokal secara turun temurun ternyata telah berhasil menyelamatkan hutan dengan mengembangkan suatu sistem pertanian berbasis pohon (wanatani) yang disebut repong. Dalam terminologi pesisir, repong adalah sebidang lahan kering yang ditumbuhi beranekaragam jenis tanaman produktif, umumnya tanaman tua (perennial crops), seperti damar, duku, durian, petai, jengkol, tangkil, manggis, kandis dan beragam jenis kayu-kayuan bernilai ekonomis serta beragam tumbuhan liar yang dibiarkan hidup (Lubis, 1997).

Mengacu pada konsep sustainable livehood, rumah tangga di desa panghasil damar memiliki banyak aset mata pencaharian, antara lain sumberdaya alam, sumberdaya manusia, keterikatan sosial, adat istiadat, dan lainlain. Keragaman sumberdaya tersebut merupakan aset berharga untuk mewujudkan ketahanan pangan yang berkelanjutan di desa penghasil damar.

Penelitian ini bertujuan untuk mengkaji ketahanan pangan rumah tangga di desa penghasil damar Kabupaten Lampung Barat. Secara khusus penelitian ini bertujuan untuk menganalisis 1) karakteristik sosial ekonomi rumahtangga; 2) keterjangkauan pangan rumahtangga; 3) ketahanan pangan rumah tangga; dan 4) faktor sosial ekonomi yang berpengaruh terha- 
dap ketahanan pangan rumah tangga di desa penghasil damar.

\section{METODE PENELITIAN}

\section{Desain, Tempat, dan Waktu Penelitian}

Penelitian ini menggunakan disain retrospective. Lokasi penelitian adalah Desa Penengah-an, yang dipilih secara purposive dengan pertimbangan bahwa desa tersebut merupakan representasi komunitas yang konsisten mempertahankan sistem wanatani repong damar (Lubis, 1997).

\section{Penarikan Contoh}

Populasi penelitian adalah seluruh (425) rumah tangga yang tinggal menetap di desa penelitian. Pemilihan rumah tangga contoh dilakukan secara purposive berdasarkan perbedaan status kepemilikan repong. Pengambilan data dilakukan dengan metode snow-ball hingga terkumpul data mengenai 30 rumah tangga pemilik repong dan 30 rumah tangga bukan pemilik repong.

\section{Pengolahan dan Analisis Data}

Data karakteristik rumah tangga, keterjangkauan pangan, dan ketahanan pangan rumah tangga dianalisis menggunakan statistik deskriptif. Faktor yang berpengaruh terhadap ketahanan pangan dianalisis menggunakan statistik inferensial. Analisis regresi dilakukan terhadap faktor-faktor yang secara teori dan ber- dasarkan analisis korelasi memiliki hubungan dengan ketahanan pangan. Cara pengolahan dan analisis beberapa variabel dapat dilihat pada Tabel 1.

\section{HASIL DAN PEMBAHASAN}

\section{Keadaan Umum Lokasi Penelitian}

Desa (pekon) Penengahan merupakan satu dari 81 desa di wilayah Pesisir Lampung Barat. Desa seluas $15.30 \mathrm{~km}^{2}$ ini terletak sekitar 275 km dari ibukota Provinsi Lampung, 35 km dari ibukota kabupaten, dan 5 km dari Pasar Krui sebagai pusat perdagangan wilayah pesisir. Desa Penengahan berada diantara Samudera Hindia di sebelah barat dan Taman Nasional Bukit Barisan selatan (TNBBS) di sebelah utara dan timur laut. Sebagian besar wilayahnya adalah perbukitan terjal yang di bawahnya mengalir banyak anak sungai (Lubis, 1997). Penduduk Penengahan berjumlah 2226 jiwa, terdiri dari $425 \mathrm{KK}$ yang tinggal mengumpul di pusat desa dengan kepadatan penduduk 148 orang $/ \mathrm{km}^{2}$. Penduduk asli yang mendiami kawasan ini adalah orang Krui yang merupakan bagian dari etnis Lampung.

\section{Karakteristik Rumah tangga Contoh}

Karakteristik rumah tangga yang dianalisis dalam penelitian ini antara lain jumlah anggota rumah tangga; pendidikan istri; luas lahan usaha; dan luas kepemilikan repong; gambaran karakteristik rumah tangga contoh dapat dilihat pada Tabel 2.

Tabel 1. Cara Pengolahan Data dan Pengkategorian Beberapa Variabel

\begin{tabular}{|c|c|c|}
\hline No & Variabel & Pengolahan dan Kategori \\
\hline 1 & $\begin{array}{l}\text { Keterjangkauan } \\
\text { Pangan }\end{array}$ & $\begin{array}{l}\text { a. Dalam penelitian ini rumah tangga disebut memiliki keterjangkauan pangan yang baik apabila } \\
\text { pengeluaran per kapitanya berada di atas garis kemiskinan dan proporsi pengeluaran } \\
\text { pangannya kurang dari } 60 \% \text { pengeluaran riil. } \\
\text { b. Pengklasifian sebagai rumah tangga miskin atau tidak miskin dilakukan dengan } \\
\text { membandingkan pengeluaran per kapita dengan batas garis kemiskinan daerah pedesaan } \\
\text { Provinsi Lampung tahun } 2007 \text { (BPS, 2008). } \\
\text { - } \quad<\text { Rp145 } 634 / \mathrm{kap} / \text { bulan = miskin } \\
\text { - } \quad \geq \text { Rp145 } 634 / \mathrm{kap} / \text { bulan = tidak miskin } \\
\text { c. Kerentanan pangan dinilai berdasarkan proporsi pengeluaran riil yang digunakan untuk } \\
\text { pangan, dengan kategori (Soekirman, 1991): } \\
\text { - } \quad \geq 60 \%=\text { rentan } \\
-\quad<60 \%=\text { aman }\end{array}$ \\
\hline 2 & $\begin{array}{l}\text { Ketahanan } \\
\text { Pangan }\end{array}$ & $\begin{array}{l}\text { a. Dalam penelitian ini rumah tangga dikategorikan tahan pangan apabila tingkat konsumsi } \\
\text { energi dan tingkat konsumsi proteinnya } \geq 90 \% \text { dari angka kecukupan yang dianjurkan, serta } \\
\text { konsumsi energi yang berasal dari pangan sumber karbohidrat } \leq 61 \% \text { dari total konsumsi } \\
\text { rumah tangga tersebut. } \\
\text { b. Menurut Pola Pangan Harapan (PPH), idealnya konsumsi energi yang berasal dari padi-padian } \\
50 \% \text {, umbi-umbian } 6 \% \text {, dan gula } 5 \% \text {. Dengan asumsi bahwa jumlah energi yang berasal dari } \\
\text { ketiga kelompok pangan sumber karbohidrat tersebut adalah } 61 \% \text { dari total konsumsi, maka } \\
\text { dalam penelitian ini digunakan kategori: } \\
-\quad \leq 61 \%=\text { beragam } \\
-\quad>61 \%=\text { tidak beragam }\end{array}$ \\
\hline
\end{tabular}


Sebagian besar rumah tangga pemilik repong (50\%) dan rumah tangga bukan pemilik $(50 \%)$ termasuk kelompok rumah tangga sedang dengan jumlah anggota 5-6 orang. Sebagian besar istri pemilik repong (57.14\%) dan istri bukan pemilik (60.71\%) hanya berpendidikan sekolah dasar. Pendidikan tinggi hanya diperoleh $3.57 \%$ kepala rumah tangga pemilik repong.

Lahan masih merupakan aset terpenting bagi penduduk pedesaan untuk menggerakkan kegiatan produksi (Tambunan, 2008) Rata-rata luas lahan yang diusahakan rumah tangga desa penelitian dapat dilihat pada Tabel 3.

Sebaran rumah tangga menurut luas kepemilikan repong menunjukkan bahwa mayoritas kepemilikan berada dalam kelompok luasan kurang dari 0.9 ha $(43.33 \%)$ dan kelompok luasan $0.9-1.7$ ha $(30.00 \%)$. Dalam penelitian ini rumah tangga yang tidak memiliki repong dapat mengelola repong orang lain dalam bentuk hubungan serah kelola (13.33\%) dan bagi hasil (3.33\%). Hubungan-hubungan tersebut dapat dianggap sebagai modal sosial, yaitu serangkaian nilai atau norma informal bersama yang memungkinkan terjadinya jalinan kerjasama antara anggota suatu komunitas (Dasgupta \& Sarageldin, 2000). Ternyata rumah tangga pemilik repong juga mengusahakan lahan orang lain dalam bentuk hubungan gadai (3.33\%). serah kelola (20.00\%) dan bagi hasil (3.33\%). Hal ini kemungkinan didorong oleh faktor adanya kemampuan modal untuk membayar lahan gadaian dan membayar upah tenaga kerja.

\section{Keterjangkauan Pangan Rumah tangga}

Berdasarkan sumbernya, pendapatan yang diperoleh rumah tangga desa penghasil damar sangat beragam, baik yang berasal dari repong (on farm), pekerjaan terkait pengelolaan damar (off farm), maupun dari pekerjaan lainnya (non farm). Struktur pendapatan tersebut dapat dilihat pada Tabel 4.

Tabel 2. Karakteristik Rumah Tangga Contoh

\begin{tabular}{|c|c|c|c|c|c|c|c|}
\hline \multirow{2}{*}{ No. } & \multirow{2}{*}{ Variabel } & \multicolumn{2}{|c|}{ Pemilik } & \multicolumn{2}{|c|}{ Bukan Pemilik } & \multicolumn{2}{|c|}{ J umlah } \\
\hline & & n & $\%$ & $n$ & $\%$ & $\mathbf{n}$ & $\%$ \\
\hline \multirow[t]{5}{*}{1.} & Jumlah Anggota Rumah Tangga & & & & & & \\
\hline & a. Kecil $(\leq 4)$ & 9 & 30.00 & 10 & 33.33 & 19 & 31.67 \\
\hline & b. Sedang (5-6) & 15 & 50.00 & 15 & 50.00 & 30 & 50.00 \\
\hline & c. Besar $(\geq 7)$ & 6 & 20.00 & 5 & 16.67 & 11 & 18.33 \\
\hline & Total & 30 & 100.00 & 30 & 100.00 & 60 & 100.00 \\
\hline \multirow[t]{6}{*}{2.} & Tingkat Pendidikan Istri & & & & & & \\
\hline & a. SD & 16 & 57.14 & 17 & 60.71 & 33 & 58.93 \\
\hline & b. SLTP & 7 & 25.00 & 5 & 17.86 & 12 & 21.43 \\
\hline & c. SLTA & 4 & 14.29 & 6 & 21.43 & 10 & 17.86 \\
\hline & d. S1 & 1 & 3.57 & 0 & 0.00 & 1 & 1.79 \\
\hline & Total & 28 & 100.00 & 28 & 100.00 & 56.00 & 100.00 \\
\hline \multirow[t]{5}{*}{3.} & Luas Lahan Usaha & & & & & & \\
\hline & a. $<1$ ha & 6 & 20.00 & 18 & 60.00 & 24 & 40.00 \\
\hline & b. 1-2 ha & 13 & 43.33 & 10 & 33.33 & 23 & 38.33 \\
\hline & c. $>2$ ha & 11 & 36.67 & 2 & 6.67 & 13 & 21.67 \\
\hline & Total & 30 & 100.00 & 30 & 100.00 & 60.00 & 100.00 \\
\hline \multirow[t]{5}{*}{4.} & Kepemilikan Repong & & & & & & \\
\hline & a. $<0.9$ ha & 13 & 43.33 & 0 & 0.00 & 13 & 43.33 \\
\hline & b. $0.9-1.7$ ha & 9 & 30.00 & 0 & 0.00 & 9 & 30.00 \\
\hline & c. $>1.7$ ha & 8 & 26.67 & 0 & 0.00 & 8 & 26.67 \\
\hline & Total & 30 & 100.00 & 0 & 0.00 & 30.00 & 100.00 \\
\hline
\end{tabular}

Tabel 3. Luas Lahan yang Diusahakan Rumah Tangga Pemilik dan Bukan Pemilik Repong

\begin{tabular}{|c|c|c|c|c|c|c|c|c|}
\hline \multirow[b]{2}{*}{ J enis Lahan } & \multicolumn{4}{|c|}{ Pemilik (ha) } & \multicolumn{4}{|c|}{ Bukan Pemilik (ha) } \\
\hline & $\begin{array}{c}\text { Rata-rata } \\
\text { (ha) }\end{array}$ & $\begin{array}{l}\text { Min } \\
\text { (ha) }\end{array}$ & $\begin{array}{l}\text { Maks } \\
\text { (ha) }\end{array}$ & $\begin{array}{c}\text { SD } \\
\text { (ha) }\end{array}$ & $\begin{array}{c}\text { Rata-rata } \\
\text { (ha) }\end{array}$ & $\begin{array}{l}\text { Min } \\
\text { (ha) }\end{array}$ & $\begin{array}{l}\text { Maks } \\
\text { (ha) }\end{array}$ & $\begin{array}{c}\text { SD } \\
\text { (ha) }\end{array}$ \\
\hline Sawah & 0.14 & 0 & 1 & 0.23 & 0.09 & 0 & 1 & 0.21 \\
\hline Kebun & 0.68 & 0 & 3 & 0.96 & 0.34 & 0 & 2 & 0.53 \\
\hline Repong “milik” sendiri & 1.33 & 0.25 & 5 & 1.14 & 0 & 0 & 0 & 0.00 \\
\hline Pengusahaan repong "milik" orang lain & 0.24 & 0 & 3 & 0.60 & 0.21 & 0 & 3.75 & 0.71 \\
\hline Total Lahan Usaha & 2.4 & 0.5 & 8.5 & 2.03 & 0.64 & 0 & 3.75 & 0.87 \\
\hline
\end{tabular}


Repong mampu memberikan pendapatan yang cukup besar bagi rumah tangga di desa penghasil damar. Secara umum pendapatan rata-rata per bulan rumah tangga pemilik repong lebih besar (Rp2 $465327 \pm$ Rp1 319 215) daripada rumah tangga bukan pe-milik (Rp1 $807385 \pm$ Rp789 156). Pada rumahtangga pemilik repong, pendapatan dari repong menempati porsi terbesar $(43.27 \%)$, diikuti oleh pendapatan dari pekerjaan lainnya (34. $24 \%)$, dan pendapatan dari pekerjaan terkait pengelolaan damar (22.49\%).

Repong merupakan suatu bentuk kebun campuran yang berisi beraneka ragam jenis tanaman. Konsekuensi dari keragaman jenis tersebut adalah keragaman hasil yang dapat diperoleh. Pendapatan dari repong dapat dibedakan menjadi pendapatan dalam bentuk pangan dan pendapatan non pangan. Sebagian besar pendapatan dari repong berbentuk non pangan (82.58\%) yaitu hasil getah damar, kayu bakar, bambu, dan lain-lain. Getah damar dapat memberikan penghasilan rutin jangka panjang bagi rumah tangga di desa panghasil damar.

Dalam penelitian ini suatu rumah tangga dapat memperoleh getah damar 20 sampai 250 $\mathrm{kg} /$ bulan, dengan hasil panen rata-rata 79.72 kg/bulan atau setara Rp. 797 222/bulan. Hal ini tidak jauh berbeda dengan hasil penelitian sebelumnya yang dilakukan ICRAF (2001) bahwa di desa pusat penghasil damar, satu rumah tangga dapat memanen rata-rata 70-100 kg getah/bulannya. Menurut Michon et al. (1998) getah damar bisa diambil dan dijual setiap saat rumah tangga membutuhkan uang kontan.

Pengelolaan repong damar juga efisien dilihat dalam penggunaan faktor produksi karena tidak diperlukan perawatan khusus, bahkan petani membiarkan pohon damar hidup dengan tanaman lain yang dapat menunjang pendapatan rumah tangga dalam bentuk kayu bakar, bambu, dan lain-lain (rata-rata Rp83 $667 /$ rumah tangga/bulan). Dilihat dari jumlahnya mungkin tidak begitu besar, namun demikian produk ini sangat dibutuhkan dan bermanfaat bagi rumah tangga pedesaan.

Selain bentuk non pangan, $17.42 \%$ hasil repong adalah bahan pangan. Repong tidak menghasilkan pangan pokok tetapi menghasilkan sayur dan buah dari beragam jenis tanaman yang hidup di dalam struktur tajuknya. Dalam penelitian ini setiap rumah tangga rata-rata dapat memperoleh pendapatan Rp185 792/bulan dari hasil buah-buahan.
Lubis (1997) menyatakan bahwa keputusan petani untuk menentukan jenis yang akan dibudidayakan di repong (damar, buahbuahan, dll.) tidak hanya didasarkan pada pertimbangan harga, tetapi pada kontribusi pendapatan rutin yang bisa diberikan dalam jangka panjang. Dalam konteks ketahanan pangan, keputusan untuk menjaga keberlanjutan sumberdaya merupakan suatu strategi untuk menjamin keberlanjutan akses pangan rumahtangga.

Selain berasal dari repong, suatu rumahtangga dapat memperoleh penghasilan dengan menjadi buruh pada pekerjaan yang berkaitan dengan pengusahaan damar. Pendapatan dari pekerjaan terkait damar rumahtangga pemilik repong sebagian besar berasal dari sektor perdagangan (53.22\%), diikuti oleh pendapatan yang berasal dari pekerjaan mileh (23.76\%), ngambica (14.63\%), ngunduh (7.49\%), dan mepat $(0.90 \%)$. Penelitian ini menunjukkan bahwa ternyata pekerjaan terkait damar juga mampu memberikan kontribusi yang cukup besar $(41.28 \%)$ terhadap total pendapatan rumah tangga bukan pemilik.

Dengan berbagai pengaturan dan jenisjenis pekerjaan tersebut hampir semua rumah tangga, atau anggota-anggota sebuah rumah tangga, baik yang memiliki repong atau tidak memiliki sama sekali bisa memperoleh peluang mendapatkan hasil repong (Lubis 1997). Dalam konteks ketahanan pangan, penyebaran kontribusi manfaat (pendapatan) dari sistem pengelolaan repong damar merupakan suatu jaring pengaman yang sangat penting bagi keterjaminan akses pangan seluruh rumah tangga desa, karena dapat menolong sejumlah rumah tangga yang tidak memiliki sumberdaya (lahan) serta kelompok rentan lainnya untuk memperoleh pendapatan dan memiliki daya beli terhadap pangan.

Pendapatan rumah tangga bukan pemilik dari pekerjaan terkait damar sebagian besar berasal dari pekerjaan ngambica (31.32\%), ngunduh (31.16\%), mileh (18.14\%), perdagangan $(17.62 \%)$, dan ngelahang $(1.77 \%)$. Perbedaan komposisi sumber pendapatan antara dua kelompok rumah tangga menunjukkan bahwa rumah tangga bukan pemilik cenderung melaksanakan jenis pekerjaan yang secara fisik lebih berat dan secara sosial statusnya lebih rendah dibandingkan dengan jenis pekerjaan yang dipilih oleh rumah tangga pemilik repong.

Rata-rata pengeluaran/kapita/bulan pada rumah tangga pemilik repong (Rp. 491 553) lebih besar daripada rumah tangga bukan pemilik (Rp. 387 048). Hal ini tidak jauh berbeda 
dengan hasil penelitian Pramono (2001) yang menyatakan bahwa rata-rata pengeluaran per kapita hasil dari repong damar cukup tinggi yaitu sebesar Rp. 541194 per kapita/bulan. Berdasarkan garis kemiskinan untuk daerah pedesaan di Provinsi Lampung (Rp. 145 634) maka tidak terdapat rumah tangga pemilik repong maupun rumah tangga bukan pemilik yang pengeluaran per kapitanya masih berada di bawah garis kemiskinan.

Penelitian ini menunjukkan bahwa sebagian besar rumah tangga pemilik repong (70.00\%) dan rumah tangga bukan pemilik (63.33\%) proporsi pengeluaran pangannya sudah di bawah $60 \%$ pengeluaran riil, namun demikian masih terdapat $30.00 \%$ rumah tangga pemilik repong dan $36.67 \%$ rumah tangga bukan pemilik yang proporsi pengeluaran pangannya masih di atas $60 \%$ pengeluaran riil.

Kerentanan suatu rumah tangga terhadap kelaparan tercermin dalam proporsi pengeluaran untuk membeli makanan. Dalam penelitian ini rumah tangga disebut memiliki keterjangkauan pangan yang baik apabila pendapatan perkapitanya berada di atas garis kemiskinan dan proporsi pengeluaran pangan- nya kurang dari $60 \%$ pengeluaran riil. Berdasarkan kategori tersebut, sebagian besar rumah tangga pemilik repong $(70.00 \%)$ dan rumah tangga bukan pemilik (63.33\%) sudah memiliki keterjangkauan pangan yang baik, namun demikian masih terdapat $30.00 \%$ rumah tangga pemilik repong dan $36.67 \%$ rumah tangga bukan pemilik yang keterjangkauan pangannya masih rendah. Menurut Maxwell dan Frankenberger (1992) rumah tangga tersebut mungkin saja saat ini mampu memenuhi kebutuhan pangannya, tetapi berada pada resiko yang besar apabila terjadi perubahan produksi dan ketersediaan pangan, perubahan harga pasar, perubahan pekerjaan dan upah, perubahan kesehatan, dan perubahan akibat terjadinya konflik.

\section{Ketahanan Pangan Rumah Tangga}

Ketahanan pangan rumah tangga dapat diketahui melalui pengumpulan data konsumsi dan hasilnya dibandingkan dengan angka kecukupan yang telah ditetapkan. Sebaran tingkat konsumsi rumah tangga pemilik repong dan bukan pemilik dapat dilihat pada Tabel 5 .

Tabel 4. Struktur Pendapatan dan Pengeluaran Rumah Tangga Pemilik dan Bukan Pemilik Repong

\begin{tabular}{|c|c|c|c|c|c|c|c|}
\hline \multirow{2}{*}{ No. } & \multirow{2}{*}{ Variabel } & \multicolumn{2}{|c|}{ Pemilik } & \multicolumn{2}{|c|}{ Bukan Pemilik } & \multicolumn{2}{|c|}{ Jumlah } \\
\hline & & Rp/bulan & $\%$ & Rp/bulan & $\%$ & Rp/bulan & $\%$ \\
\hline \multirow[t]{7}{*}{1.} & Sumber Pendapatan & & & & & & \\
\hline & a. Repong (on farm) & 1066681 & 43.27 & 0 & 0.00 & 1066681 & 24.96 \\
\hline & 1. Pangan & 185792 & 17.42 & 0 & 0.00 & 185792 & 4.35 \\
\hline & 2. Non Pangan & 880889 & 82.58 & 0 & 0.00 & 880889 & 20.62 \\
\hline & b. Terkait damar & 554488 & 22.49 & 746174 & 41.28 & 1300662 & 30.44 \\
\hline & $\begin{array}{l}\text { c. Lainnya } \\
\text { (sawah, kebun, dll.) }\end{array}$ & 844157 & 34.24 & 1061211 & 58.72 & 1905368 & 44.59 \\
\hline & Total & 2465326 & 100.00 & 1807385 & 100.00 & 4272711 & 100.00 \\
\hline \multirow[t]{8}{*}{2.} & Pendapatan terkait damar & & & & & & \\
\hline & a. Perdagangan & 295111 & 53.22 & 131458 & 17.62 & 426569 & 32.80 \\
\hline & b. Ngunduh & 41500 & 7.49 & 232483 & 31.16 & 273983 & 21.06 \\
\hline & c. Mepat & 5000 & 0.90 & 0 & 0.00 & 5000 & 0.38 \\
\hline & d. Ngelahang & 0 & 0.00 & 13200 & 1.77 & 13200 & 1.01 \\
\hline & e. Ngambica & 81108 & 14.63 & 233672 & 31.32 & 314780 & 24.20 \\
\hline & f. Mileh & 131769 & 23.76 & 135362 & 18.14 & 267131 & 20.54 \\
\hline & Total & 554488 & 100.00 & 746175 & 100.00 & 1300663 & 100.00 \\
\hline \multirow[t]{4}{*}{3.} & Pengeluaran RT & & & & & & \\
\hline & a. Pangan & 1104956 & 44.82 & 936720 & 51.83 & 2041676 & 47.78 \\
\hline & b. Non Pangan & 1360371 & 55.18 & 870665 & 48.17 & 2231036 & 52.22 \\
\hline & Total & 2465327 & 100.00 & 1807385 & 100.00 & 4272712 & 100.00 \\
\hline \multirow{2}{*}{ No. } & \multirow{2}{*}{ Variabel } & \multicolumn{2}{|c|}{ Pemilik } & \multicolumn{2}{|c|}{ Bukan Pemilik } & \multicolumn{2}{|c|}{ Jumlah } \\
\hline & & $\mathrm{n}$ & $\%$ & $\mathrm{n}$ & $\%$ & $\mathrm{n}$ & $\%$ \\
\hline \multirow[t]{4}{*}{4.} & PengeluaranPangan & & & & & & \\
\hline & a. $<60 \%$ & 21 & 70.00 & 19 & 63.33 & 40 & 66.67 \\
\hline & b. $\geq 60 \%$ & 9 & 30.00 & 11 & 36.67 & 20 & 33.33 \\
\hline & Total & 30 & 100.00 & 30 & 100.00 & 60 & 100.00 \\
\hline
\end{tabular}


Tabel 5. Tingkat dan Keragaman Konsumsi Rumah Tangga Pemilik dan Bukan Pemilik Repong

\begin{tabular}{|c|c|c|c|c|c|c|c|}
\hline \multirow{2}{*}{ No. } & \multirow{2}{*}{ Variabel } & \multicolumn{2}{|c|}{ Pemilik } & \multicolumn{2}{|c|}{ Bukan Pemilik } & \multicolumn{2}{|c|}{ J umlah } \\
\hline & & $\mathbf{n}$ & $\%$ & $\mathbf{n}$ & $\%$ & $\mathbf{n}$ & $\%$ \\
\hline \multirow[t]{7}{*}{1.} & Tingkat Kecukupan Energi & & & & & & \\
\hline & a. Defisit berat (<70\% AKE) & 0 & 0.00 & 0 & 0.00 & 0 & 0.00 \\
\hline & b. Defisit sedang (70-79\% AKE) & 0 & 0.00 & 5 & 16.67 & 5 & 8.33 \\
\hline & c. Defisit ringan (70-89\% AKE) & 7 & 23.33 & 8 & 26.67 & 15 & 25.00 \\
\hline & d. Normal $(90-119 \%$ AKE $)$ & 18 & 60.00 & 14 & 46.67 & 32 & 53.33 \\
\hline & e. Lebih( >119\% AKE) & 5 & 16.67 & 3 & 10.00 & 8 & 13.33 \\
\hline & Total & 30 & 100.00 & 30 & 100.00 & 60 & 100.00 \\
\hline \multirow[t]{7}{*}{2.} & Tingkat Kecukupan Protein & & & & & & \\
\hline & a. Defisit berat (<70\% AKP) & 6 & 20.00 & 8 & 26.67 & 14 & 23.33 \\
\hline & b. Defisit sedang (70-79\% AKP) & 3 & 10.00 & 4 & 13.33 & 7 & 11.67 \\
\hline & c. Defisit ringan (70-89\% AKP) & 4 & 13.33 & 4 & 13.33 & 8 & 13.33 \\
\hline & d. Normal (90-119\% AKP) & 8 & 26.67 & 6 & 20.00 & 14 & 23.33 \\
\hline & e. Lebih( $>119 \%$ AKP) & 9 & 30.00 & 8 & 26.67 & 17 & 28.33 \\
\hline & Total & 30 & 100.00 & 30 & 100.00 & 60 & 100.00 \\
\hline \multirow[t]{4}{*}{3.} & $\begin{array}{l}\text { Proporsi energi dari kelompok pangan sumber } \\
\text { karbohidrat }\end{array}$ & & & & & & \\
\hline & a. Beragam ( $\leq 61 \%)$ & 12 & 40.00 & 10 & 33.33 & 22 & 36.67 \\
\hline & b. Tidak beragam (>61\%) & 18 & 60.00 & 20 & 66.67 & 38 & 63.33 \\
\hline & Total & 30 & 100.00 & 30 & 100.00 & 60 & 100.00 \\
\hline
\end{tabular}

Tabel 5 menunjukkan bahwa tingkat konsumsi energi sebagian besar rumah tangga pemilik repong $(76.67 \%)$ dan rumah tangga bukan pemilik (56.67\%) sudah $\geq 90 \%$ dari angka kecukupan yang dianjurkan dan tidak terdapat rumah tangga yang mengalami defisit energi tingkat berat.

Selain energi, protein merupakan zat gizi yang diperlukan tubuh untuk membentuk selsel baru, tanpa adanya protein pertumbuhan tubuh akan terganggu. Tingkat konsumsi protein sebagian besar rumah tangga pemilik repong (56.67\%) dan rumah tangga bukan pemilik $(46.67 \%)$ sudah $\geq 90 \%$ dari angka kecukupan yang dianjurkan, namun ternyata masih terdapat $20.00 \%$ rumah tangga pemilik repong dan $26.67 \%$ rumah tangga bukan pemilik yang mengalami defisit protein tingkat berat.

Dalam konsumsi pangan, selain kuantitas juga harus diperhatikan masalah kualitas. Tabel 5 menunjukkan bahwa hanya $40.00 \%$ rumahtangga pemilik repong dan $33.33 \%$ rumah tangga bukan pemilik yang pola konsumsinya sudah beragam, sementara $60.00 \%$ rumah tangga pemilik repong dan $66.67 \%$ rumah tangga bukan pemilik masih belum beragam.

Dalam penelitian ini rumah tangga disebut tahan pangan bila tingkat konsumsi energi dan tingkat konsumsi proteinnya $\geq 90 \%$ dari angka kecukupan yang dianjurkan, serta konsumsi energi yang berasal dari pangan sumber karbohidrat $\leq 61 \%$ dari total konsumsi rumah tangga. Berdasarkan batasan tersebut, hanya $33.33 \%$ rumah tangga pemilik repong dan $23.33 \%$ rumah tangga bukan pemilik yang ter-golong tahan pangan, dengan demikian masih terdapat $66.67 \%$ rumah tangga pemilik repong dan $76.67 \%$ rumah tangga bukan pemilik yang belum tahan pangan.

Informasi di atas menunjukkan bahwa walaupun pendapatan rumah tangga pemilik repong dan rumah tangga bukan pemilik cukup tinggi tetapi masih rendah ditinjau dari segi kuantitas dan kualitas konsumsi. Menurut Berg (1986) pertambahan pendapatan tidak selalu membawa perbaikan pada konsumsi pangan, dengan pengeluaran pangan lebih besar orang mungkin akan makan lebih banyak, tetapi belum tentu kualitas pangan yang dibeli lebih baik.

Faktor yang Berpengaruh terhadap Ketahanan Pangan Rumah Tangga

Untuk mengetahui beberapa faktor yang berpengaruh terhadap ketahanan pangan rumah tangga digunakan analisis regresi. Analisis regresi menunjukkan bahwa faktor yang berpengaruh nyata terhadap tingkat konsumsi energi adalah jumlah anggota rumah tangga $\left(x_{1}\right) \quad(P<0.01)$, luas kepemilikan repong $\left(x_{2}\right)$ $(P<0.05)$, dan pengeluaran pangan $\left(x_{3}\right)$ $(P<0.01)$ dengan model persamaan: $y=93.528$ $-0.406 x_{1}+0.238 x_{2}+0.483 x_{3}$ dan $R^{2}=0.526$. Faktor yang berpengaruh nyata terhadap tingkat konsumsi protein adalah jumlah anggota rumah tangga $\left(\mathrm{X}_{1}\right) \quad(\mathrm{P}<0.01)$ dan pengeluaran pangan $\left(\mathrm{x}_{2}\right)(\mathrm{P}<0.01)$ dengan model persamaan: $y=85.546-0.538 x_{1}+0.726 x_{2}$ dan $R^{2}=0.678$. Faktor yang berpengaruh nyata terhadap keragaman konsumsi adalah jumlah anggota rumah tangga $\left(x_{1}\right) \quad(P<0.01)$ dan luas kepemilikan repong $\left(x_{2}\right) \quad(P<0.05)$ dengan model persamaan: $\mathrm{y}=64.381-0.375 \mathrm{x}_{1}+0.303 \mathrm{x}_{2}$ dengan $R^{2}=0.365$. 
Analisis regresi menunjukkan bahwa jumlah anggota rumah tangga berpengaruh negatif sangat nyata terhadap ketiga indikator ketahanan pangan rumah tangga (tingkat konsumsi energi, protein serta keragaman konsumsi) di desa penghasil damar. Fungsi utama repong adalah sebagai sumber pendapatan dari berbagai komoditi yang ada di dalamnya. Peningkatan jumlah anggota rumah tangga tanpa diimbangi peningkatan sumberdaya dan sumber mata pencaharian penunjang ekonomi akan menyebabkan alokasi pemenuhan pangan per anggota rumah tangga menjadi rendah.

Dupain (1994) diacu dalam de Foresta et al. (2000) menunjukkan bahwa sejak beberapa tahun yang lalu lahan pertanian di desa utama penghasil damar sudah tidak bisa diperluas lagi. Hampir tidak ada aliran penduduk yang datang, tetapi perpindahan penduduk ke luar desa merupakan faktor yang penting. Penelitian Kusters (2006) menunjukkan bahwa $58.48 \%$ dari keseluruhan rumah tangga sekurang-kurangnya memiliki satu atau lebih anggotanya yang tinggal di luar desa. Kepala keluarga pergi ke desa lain untuk membuka ladang padi dan kebun baru, sementara generasi muda kebanyakan pergi ke kota untuk mencari pekerjaan non pertanian. Untuk mengatasi persoalan pangan akibat pertambahan penduduk, secara teoritis masyarakat di desa penghasil damar mempunyai tiga pilihan, yaitu 1) memperluas lahan pertanian dengan membuka lahan di wilayah lain; 2) meningkatkan pendapatan sebagai buruh non tani; dan 3) meperbesar tingkat pengembalian lahan (return of land). Saat ini strategi yang diambil nampaknya lebih banyak pada strategi pertama dan kedua.

Analisis regresi menunjukkan bahwa tingkat pendidikan istri tidak berpengaruh nyata terhadap tingkat konsumsi energi dan protein serta keragaman konsumsi rumah tangga. Tingkat pendidikan istri yang lebih tinggi tanpa disertai dengan pengetahuan tentang gizi kemungkinan menjadi penyebab mengapa hal tersebut tidak berpengaruh nyata terhadap tingkat dan keragaman konsumsi rumah tangga.

Penguasaan aset yang paling signifikan mencerminkan tingkat ekonomi petani adalah luas pemilikan dan penguasaan lahan (Swastika et al., 2000). Analisis regresi menunjukkan bahwa luas kepemilikan repong berpengaruh nyata terhadap tingkat konsumsi energi rumah tangga. Meningkatnya kepemilikan repong akan menyebabkan peluang untuk meningkatkan pendapatan semakin besar. Pada suatu sistem budidaya yang tidak menghasilkan pangan pokok, peningkatan pendapatan sangat penting artinya bagi peningkatan daya beli rumah tangga. Dengan daya beli yang semakin baik maka rumah tangga akan lebih mampu untuk memenuhi kebutuhan energi setiap anggotanya.

Analisis regresi menunjukkan bahwa luas kepemilikan repong tidak berpengaruh nyata terhadap tingkat konsumsi protein namun berpengaruh nyata terhadap keragaman konsumsi pangan rumah tangga. Walaupun repong tidak menghasilkan pangan pokok namun repong dapat memberikan makanan tambahan berupa beranekaragam jenis sayur dan buah. Konsumsi sayur dan buah yang lebih tinggi kemungkinan menjadi penyebab lebih beragamnya konsumsi rumah tangga dengan tingkat pemilikan repong lebih luas, namun karena sayur dan buah bukan merupakan jenis pangan sumber protein maka kepemilikan repong menjadi tidak berpengaruh nyata terhadap tingkat konsumsi protein rumah tangga.

Menurut Harper dalam Suhardjo (1989) pengeluaran pangan merupakan salah satu faktor utama yang mempengaruhi konsumsi pangan, dalam penelitian ini analisis regresi juga menunjukkan bahwa pengeluaran pangan berpengaruh positif sangat nyata terhadap peningkatan konsumsi energi dan protein rumah tangga, namun tidak berpengaruh nyata terhadap keragaman konsumsi. Hal ini terjadi karena rumah tangga dengan pengeluaran pangan lebih tinggi cenderung menggunakan pengeluarannya untuk meningkatkan jumlah (kuantitas) konsumsi pangan sumber karbohidrat. Menurut Ariani (2007) walaupun secara kuantitas terpenuhi namun jika pangan yang dikonsumsi kurang beraneka ragam dapat berdampak negatif terhadap pertumbuhan fisik dan kecerdasan manusia. Dengan demikian upaya perbaikan kualitas konsumsi rumah tangga di desa penghasil damar tidak cukup hanya dilakukan dengan peningkatan pengeluaran pangan tetapi juga harus diimbangi dengan peningkatan pengetahuan tentang pangan dan gizi. Pengetahuan tentang pangan dan gizi seimbang diharapkan dapat menjadi pedoman bagi rumah tangga untuk lebih bijaksana dalam mengalokasikan pengeluaran pangan.

\section{KESIMPULAN}

Mayoritas rumah tangga pemilik repong (50\%) dan rumah tangga bukan pemilik (50\%) tergolong rumah tangga sedang. Sebagian besar istri pemilik repong $(57.14 \%)$ dan istri bu- 
kan pemilik $(60.71 \%)$ hanya mengenyam pendidikan SD. Mayoritas kepemilikan repong berada pada kelompok luasan $<0.9$ ha $(43.33 \%)$ dan pada kelompok luasan adalah 0.9-1.7 ha $(30.00 \%)$.

Sebagian besar rumah tangga pemilik repong $(70.00 \%)$ dan rumah tangga bukan pemilik (63.33\%) sudah memiliki keterjangjangkauan yang baik terhadap pangan, namun demikian masih terdapat $30.00 \%$ rumah tangga pemilik repong dan $36.67 \%$ rumah tangga bukan pemilik yang masih rendah keterjangkauan pangannya.

Hanya $33.33 \%$ rumah tangga pemilik repong dan $23.33 \%$ rumah tangga bukan pemilik yang tergolong tahan pangan.

Faktor yang berpengaruh nyata terhadap tingkat konsumsi energi adalah jumlah anggota rumah tangga, luas kepemilikan repong, dan pengeluaran pangan. Faktor yang berpengaruh nyata terhadap tingkat konsumsi protein adalah jumlah anggota rumah tangga dan jumlah pengeluaran pangan. Faktor yang berpengaruh nyata terhadap keragaman konsumsi adalah jumlah anggota rumah tangga dan luas kepemilikan repong.

\section{DAFTAR PUSTAKA}

Ariani M, Purwantini TB. 2007 Analisis Konsumsi Pangan Rumah tangga Pasca Krisis Ekonomi di Propinsi Jawa Barat. Puslitbang Sosial Ekonomi Pertanian, Bogor.

Berg A. 1986. Peranan Gizi Dalam Pembangunan. Penerbit Rajawali, Jakarta.

[BPS], 2008. Perkembangan Beberapa Indikator Sosial Ekonomi Indonesia. CV. Dharma Putra, Jakarta.

Dasgupta P, Serageldin I. 2000. Social Capital: A Multifaced Perspective. The World Bank. Washington DC. USA.

De Foresta $\mathrm{H}$, Kusworo $\mathrm{A}$, Michon $\mathrm{G}$, dan Djatmiko WA. 2000. Ketika Kebun Berupa hutan: Agroforest Khas Indonesia. SMT Grafika, Jakarta.
[ICRAF]. 2001. The Krui agroforests: A Model of Sustainable Community-Based Management. ASB Policy Brief No. 02. Nairobi, Alternatives to Slash-and-Burn (ASB) Programme.

Keraf AS. 2006. Etika Lingkungan. Penerbit Buku Kompas.

Kusters K. 2006. Repong Damar di Pesisir Lampung Barat: Mata Pencaharian dan Pengaturan Kepemilikan Lahan. Makalah disampaikan pada ekspose di Bapeda Lampung Barat, Liwa.

Lubis Z. 1997. Repong Damar: Kajian tentang Pengambilan Keputusan dalam Pengelolaan Lahan Hutan di Pesisir Krui, Lampung Barat. Working Paper No. 20. http://cgiar.org/cifor.

Maxwell S, Frankenberger TR. 1992. Household Food Security: Concepts, Indicators, Measurements. IFAD, Rome and UNICEF, New York.

Michon G, de Foresta H, Kusworo A, Levang P. 1998. The Damar Agroforest of Krui, Indonesia: Justice for Forest Farmers. In C. Zerner, ed. People, plants and justice. Columbia University Press, Columbia, USA.

Pramono H. 2001. Ketergantungan Masyarakat terhadap Repong Damar di Pesisir Krui Lampung Barat. Tesis Program Studi PSL Pascasarjana IPB, Bogor.

Soekirman. 1991. Kebijakan Pangan dan Gizi dalam Upaya Peningkatan Kualitas Hidup. Gizi Indonesia. 13 (1):16-30

Suhardjo. 1989. Sosio Budaya Gizi. Pusat Antar Universitas-IPB, Bogor.

Swastika DKS, Djulin A, Ramli R. 2000. Struktur Penguasaan Lahan dan Pendapatan Rumah tangga Tani. Pusat Penelitian dan Pengembangan Sosial Ekonomi Pertanian, Litbang Pertanian, Bogor.

Tambunan, T. 2008. Ketahanan Pangan di Indonesia. Mengidentifikasi Beberapa Penyebab. Pusat Studi Industri dan UKM Universitas Trisakti, Jakarta. 